\title{
PReS-FINAL-2246: CBCT versus orthopan tomogram detecting TMJ alteration in JIA
}

\author{
P Arvonen $^{1 *}$, J Naujokaityte ${ }^{1}$, M Arvonen $^{2}$, J Niinimäki ${ }^{3}$, P Vähäsalo ${ }^{4}$, P Pirttiniemi ${ }^{1}$ \\ From 20th Pediatric Rheumatology European Society (PReS) Congress \\ Ljubljana, Slovenia. 25-29 September 2013
}

\section{Introduction}

TMJ is frequently affected in JIA, but there is no data comparing imaging techniques in detecting TMJ bone changes.

\section{Objectives}

The purpose was to compare the usefulness of $\mathrm{CBCT}$ and OPG in detecting condylar changes, including erosion, flattening and mandibular asymmetry in children with JIA.

\section{Methods}

61 JIA patients with TMJ alterations were imaged by OPG and CBCT (mean age 11 years, 5-17 years). Mandibular ramus height was measured on OPG (distance between point Condylion and Gonion) and condyle height on CBCT (distance between incisura and point Condylion). The difference between right and left sides was calculated. Condylar changes were graded in five damage scores (Billiau 2007) by two dentists.

\section{Results}

CBCT was superior to OPG in inter-observer reproducibility in Billiau classification $\left(r^{2}=0.835\right.$ vs. $r^{2}=0.64$, 122 joints). Classification correlated between OPG and CBCT $(\mathrm{R}=0.637, \mathrm{p}<0.001)$. OPG was superior to $\mathrm{CBCT}$ in repeatability of measurement of asymmetry of ramus or condyle heights $\left(\mathrm{r}^{2}=0.921\right.$ vs. 0.766$)$. Asymmetry during opening of mouth was correlating better with OPG than CBCT asymmetry measurements $(R=-0.624$, vs. -0.519$)$ and they were correlating $(0.742, \mathrm{p}<0.001)$.

\section{Conclusion}

OPG is a valid method in detecting asymmetry of mandibular ramus lengths in JIA patients. CBCT is superior

${ }^{1}$ Department of Dentistry, Oulu University, Oulu, Finland

Full list of author information is available at the end of the article to OPG in detecting bony TMJ changes because it detects three dimensionally the bony structures with accuracy. In CBCT there are more sources of errors in detecting the condyle height.

\section{Disclosure of interest}

None declared.

\section{Authors' details}

${ }^{1}$ Department of Dentistry, Oulu University, Oulu, Finland. ${ }^{2}$ Pediatrics, Kuopio University Hospital, Kuopio, Finland. ${ }^{3}$ Radiology, Oulu University Hospital, Oulu, Finland. ${ }^{4}$ Pediatrics, Oulu University Hospital, Oulu, Finland.

Published: 5 December 2013

\section{doi:10.1186/1546-0096-11-S2-P236}

Cite this article as: Arvonen et al:: PReS-FINAL-2246: CBCT versus orthopan tomogram detecting TMJ alteration in JIA. Pediatric Rheumatology 2013 11(Suppl 2):P236.
Submit your next manuscript to BioMed Central and take full advantage of:

- Convenient online submission

- Thorough peer review

- No space constraints or color figure charges

- Immediate publication on acceptance

- Inclusion in PubMed, CAS, Scopus and Google Scholar

- Research which is freely available for redistribution
() Biomed Central 